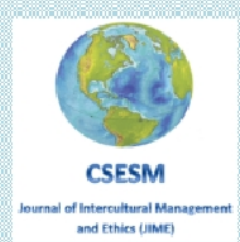

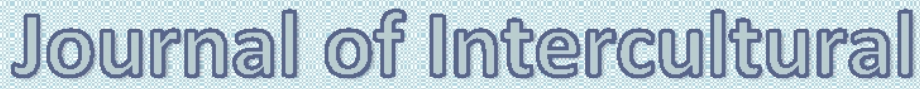

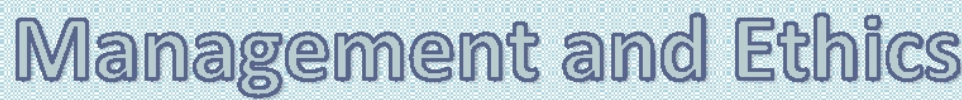

\author{
IOME
}

ISSN 2601 - 5749, ISSN-L 2601 - 5749

\section{published by zy \\ Center for Socio-Economic Studies and Multiculturalism \\ lasi, Romania \\ Waw csesmorg}




\section{TABLE OF CONTENT}

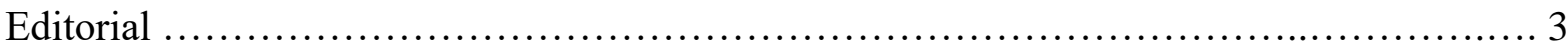

Liviu Warter

Ethics \& Consciousness in Organizations: A Conceptual Hierarchical Model

.5

Hershey H. Friedman, Kenneth A. Globerman

Ethical Challenges in Online Research.

Bianca Hanganu, Irina Smaranda Manoilescu, Beatrice Gabriela Ioan

Ethical Challenges of Digital Technologies in Covid-19 Pandemic Management. .25

Simina Petra Simion; Harald Jung

The Image of the Male and Female Doctors in the Covid-19 Pandemic. The First Pandemic with Woman Doctors in the Front Line .39 Orsolya Horber, Karoly Zilahi

Why Nations Collapse: The Rise and Fall of The United States 45

Hershey H. Friedman, Sarah Hertz

Egocentric Perceptions and Self-Serving Bias in Negotiations: Fairness, Dynamics, and Ethics 61

Oleg Komlik 


\title{
THE IMAGE OF THE MALE AND FEMALE DOCTORS IN THE COVID-19 PANDEMIC. THE FIRST PANDEMIC WITH WOMAN DOCTORS IN THE FRONT LINE
}

\author{
Orsolya Horber $^{1 *}$, Karoly Zilahi ${ }^{1}$ \\ ${ }^{1}$ Praxis Dr.Horber-Dr.Zilahi, Satu Mare, Romania \\ *corresponding author: E-mail: praxis@ horber-zilahi.ro
}

\begin{abstract}
The last great pandemic, the Spanish flu of 1918, took place at a time when the number of women graduating from medical schools was still very low. Assistants, nurses, and volunteer helpers worked in military and camp hospitals in World War I in treating war wounds or injuries and caring for the flu patients. However, the COVID-19 pandemic is the first one in which female professionals participated in the front line, working as doctors or pharmacists. During turbulent times like the pandemic, the physician (regardless of gender) as a person has become vulnerable, the image and the control of image are much more difficult. Throughout history, the medical community has sought to create an image appropriate to the current social, historical, and political era. At the same time, the doctor more or less successfully forms the individual image in the local community, where he/she works. In calm periods and ages, doctors have the time and material resources necessary for their professional and individual development. During historical, political, social, and health crises (such as wars, dictatorships, recessions, epidemics) the large number of patients, the struggle with time and limited resources lead to a disorganized, spontaneous medical activity. The difference between organized and disorganized activity is the image. During the epidemics, the doctor-patient relationship becomes more superficial, subordinated to public health and the collective good, the personality of the doctor and of the patient changes. For that reason, the control of image is much more complicated today, in a pandemic, in a society based on permanent communication and social media.
\end{abstract}

Keywords: image, image control, doctors, pandemic, COVID-19, gender

\section{Introduction}

The COVID-19 disease was declared by World Health Organization (WHO) a pandemic on March 11th, 2020 (WHO, 2020).

The population, as well as the European administrative and political system, respectively global, was taken by surprise, although from several points of view (climate change, transformation of the surrounding nature, globalization) the outbreak of an epidemic was inevitable. Health systems began fighting the disease with existing doctors, who worked and practiced the art of healing at the time of the pandemic.

Gender issues have never been a fundamental issue (like many other questions) not having enough time in a critical situation, which required prompt reactions.

What is certain is that the COVID-19 pandemic is the first in which female professionals participated in the front line, working as doctors.

The last great pandemic, the Spanish flu of 1918, took place at a time when the number of women graduating from medical schools was still very low. Assistants, nurses, and volunteer helpers worked in military and camp hospitals in World War I in treating war wounds and injuries and caring for the flu patients. However, at that time the number of women- doctors was very small. 


\section{The beginnings of the art of healing for women in Romania}

When Emilie Pankhurst gave her important speech on women's rights and their situation in society on March 24th, 1908 in London, the University of Cluj, Romania had already opened its doors to women, the Faculty of Mathematics and Natural Sciences in 1897, three years later, in 1900 Faculty of Medicine, and in 1903 the Faculty of Pharmacy. It was the period when Maria Cutarida-Cratunescu (1857-1919), the first woman doctor in Romania graduated the Faculty of Medicine in Montpellier and became doctor in medicine in 1884 after doctoral training in Paris. She presented the paper ("Le travail de la femme en Roumanie"-"Work of Women in Romania") at the Feminist Congress in Paris in 1900 (Marcu \& Ilinca, 2009).

The first women doctors and pharmacists in Romania and the Austro-Hungarian Monarchy graduated in the early years of the twentieth century, decades later when French, Swiss and Belgian faculties accepted women among their students. The acceptance of female doctors was much more difficult in this part of Europe. Several professors considered that women are incapable of practicing medicine, citing the "feminine nature" as the cause. However, the professor of morpho-pathology, Antal Genersich from Cluj promoted the education of women in medicine, noting that some patients do not always have full confidence in male doctors. Therefore, Professor Genersich's three daughters enrolled at the faculty of Medicine. Unfortunately, two of them died during the studies: Evelin (1869-1888) passed away in the second year of her medical studies in Zurich (Thomann Tewarson, 2018), and Gabriella (1882-1908) died in the fourth year of faculty. Lastly, the third sister Genersich Margit (1878-1918) became the second female doctor who graduated the Faculty of Medicine in Budapest in 1902, after Sarolta Steinberger, who obtained the title of doctor in 1900 (Bruckner, 2019). Margit specialized in ophtalmology and she treated during the First World War the returned soldiers with eye wounds. She became a victim of the Spanish flu in 1918 (Bruckner, 2019).

The struggle was hard, but in the end, society accepted women as doctors or pharmacists. At first, they dealt with pediatrics and childcare, later they became more active, applying for other specialties, even participating in medical conferences.

Educated and independent, often from a multicultural background, medical and pharmacy women graduates obtained a practice license and work alone or marry their colleagues and run a medical practice or pharmacy together. For instance, Scheint Frida, the first woman- pharmacist in Transylvania, a graduate of Wien and Seidnitzer Hugo founded a pharmacy together in Bistrita (Peter, 2005).

Several women doctors (Berall Henriette, Kohn Margit, Nadler Eta, Kassriel Blanka) worked also at the Jewish Hospital in Satu- Mare (Bet Hacholim Haivri), which opened in the spring of 1927. They specialized in laboratory medicine, pediatrics, internal medicine, ophthalmology, often graduating from universities in Prague or Vienna. Being already specialist doctors in the 1920s, their participation in 1918-1919 in the Spanish flu pandemic is not excluded. In 1944, like most Jewish doctors in Satu-Mare, they were largely deported and killed in concentration camps (Csirak, 1997).

\section{Doctors and epidemics. The first women nurses and doctors in wars and epidemics.}

During the great plague epidemic in London (1665-1666) Sydenham himself, the practitioner, admitted that he left the city (Szumowszki, 1939). At that time the social sensitivity of the doctor was an unknown term. The state was not concerned with public health either.

The emergence of human rights gradually changed the doctor-patient relationship. Instead of medieval "xenodochium", hospitals and orphanages set up. Doctors implemented 
measures to create cemeteries and eliminate outbreaks (Outram, 2008).

Moses Mendelssohn promoted tolerance between religions. During the Enlightenment, the doctor gradually became more tolerant, more sensitive, a reader (types of images characteristic of the Enlightenment presented by Dorina Outram).

Sydenham observed the characteristics of the plague epidemic as a medical practitioner but he did not feel responsible for treating sick people. Gradually the doctor observed nature and human being and became more connected to other human beings (patients, but also doctors) through common values, through freedom or objectivity, as Habermas stated (Outram, 2008). These values became important in the Enlightenment period. With the evolution of the doctor, the status and position of the patient also changed, so that the beginnings of individual responsibility are found in the Enlightenment (Outram, 2008).

In the early Christianity and continuing in the Middle Ages the care of the sick was also performed by caregivers or nuns. But the professionalization and secularization of women's healing and care work took place much later. In the 1850s Florence Nightingale together with 38 nurses set out in Turkey during the Crimean War. They also participated in the eradication of the cholera epidemic, which broke out during that time (Schott, 1993).

The activity of layman caregivers has gradually being integrated into the programs of social reforms and feminist movements.

During the First World War and the Spanish flu epidemic, the more or less specialized work of volunteers or members of the Red Cross Society, meant a lot (Schott, 1993). Women doctors were already involved, but given the small number of medical graduates, they participated only very isolated or not at all in the first line.

\section{The doctor-patient relationship in calm and turbulent times. The image of the male and female doctors in a pandemic}

When in the 2nd century, A.D. the number of doctors in Rome was growing considerably, the citizens born in the city were not yet engaged in healing to earn money. The doctors were mostly those who came from other provinces, especially Greeks. "Romana gravitas non exercet medicam artem" ("Romans with dignity do not practice medical art ") Plinius wrote. Romans approached with medicine only as a part of education and the acquisition of general knowledge and they only healed their family members. Plinius goes on to say that doctors experiment and kill without restriction because there is no law that would punish the lack of knowledge (Szumowszki, 1939). In the ancient medical schools, the duration of studies was very short, often only six months. Thus, the perception of people and patients about doctors was largely negative; according to Plinius they only advertised and praised their knowledge and their methods of treatment (Szumowszki, 1939).

Nowadays, during the COVID-19 pandemic, the doctor and medicine are very frequently present in people's lives. By publicizing the medical activity, the doctor- as a person has become vulnerable, his/her image and image control being much more difficult in contemporary society.

Studying the transformations in the history of medicine, image analysis shows some similarities.

Throughout history, the medical community has sought to create an image appropriate to the respective social, historical, and political era. At the same time, the doctor more or less successfully forms the individual image in the local community, where he/she works.

In calm periods and ages, doctors have the time and material resources necessary for their professional and individual development. During historical, political, social, and health crises (wars, dictatorships, recessions, epidemics) the large number of patients, the struggle with time and limited resources lead to a disorganized, spontaneous medical activity (Loue, 
2011).

The difference between organized and disorganized activity is the image. According to this theory, the image is formed in the same way in the 2 nd or 21 st century, in the Roman Empire, or in contemporary Romania. But image control is much more difficult today, in a pandemic, in a society based on permanent communication.

The passage of time in a serene and peaceful period creates a possibility for personal development in the age of individualism and the communication may become more difficult or easier in the case of a long- term doctor- patient relationship.

Mihaly (Michael) Balint, the famous psychologist and doctor, Ferenczi Sandor's student, who worked in the UK published the paper "The Doctor, His Patient and the Illness" (which will form the basis of the Balint group) stated that the doctor-patient relationship can evolve along the time in several directions:

- Continuing the relationship, even its development, thus better satisfying the expectations of the doctor and of the patient. The patient is grateful because coming back after variable intervals does not have to explain everything from the beginning.

- The patient leaving, changing the doctor (although there is self-selection of the patient regarding the doctor). The patient often isolates from a doctor who knows several aspects of his/her life or health (although the patient knows the obligation of the doctor of keeping professional secrecy).

- The patient becomes dependent of the doctor.

All three possibilities can occur during a crisis, respectively through what we are going through today, the COVID-19 pandemic.

Although the doctor has several patients, and the patient in the context of a disease only one attending physician, the doctor is present in the case of each patient here and now. Therapy becomes special in situations when the doctor's personality plays an important role. The percentage of doctors with modified personality and burnout is high in the epidemic. Isolation, abandonment, and neglect of personal relationships often lead to occupational diseases (Balint, 1957).

\section{Practicing medicine during the pandemic- a professional or moral duty?}

The doctor has a duty and he/she performs his/her work, taking into account not only the consequences of the facts but also other important aspects. W.D. Ross, the creator of the theory of "prima facie" duties (Dancy, 2006), states that the variety of aspects and things important in the case of duties is very large, and a strict list of morally significant aspects cannot be drawn up. Doctors also work out of generosity ("helping others, where possible") or out of fairness in dealing with others. Ross argues that primary duties are to help others, to keep our promises, to return good deeds, not to disappoint those who rely on us (Dancy, 2006). Practicing medicine during the pandemic it is a"prima facie" duty for doctors because it is an act of keeping the promise, an oath after graduating the faculty of medicine.

During wars and epidemics, the short time and the large numbers of patients often lead to chaotic and disorganized activity. In time, doctors encounter the dark side of life, the loss of illusions, aging, feelings of loneliness, uselessness. After experiencing many painful decisions, tragedies and sufferings, permanent ethical self-control, exaggerated bureaucracy, even during an epidemic, the doctor inevitably becomes demoralized (Balint, 1957).

Female doctors know the phenomenon of burnout, of exaggerated fatigue in a pandemic only in the last century, admission to colleges for women being possible only from the late 19th century, early 20th century. The COVID-19 pandemic is their first major epidemic, their first experience with the feeling of being able to help and the feeling of not being able to help in extreme conditions. 


\section{Losses and gains. Conclusions.}

Practicing medicine in a pandemic period is full of difficulties, life-threatening situations, under special moral pressure, but it can also represent a road, in which fellow travelers appear and disappear.

The young doctor who appears in the life and work of the more experienced and educated doctor will be mentored. The older healer will receive the reward of the presence of the colleague, eventually, he will be saved from professional loneliness (Balint, 1957). This is an example of teamwork in turbulent times.

The practice of medicine during a pandemic is a long and difficult road, which can give the doctors and other health care workers the possibility of psychological and moral change and development. However during the pandemic the doctor-patient relationship becomes more superficial, subordinated to public health requirement of promoting the collective good. Therefore, the personality of the doctor, but also that of the patient change.

Female doctors are participating in large numbers for the first time in the history of medicine at the forefront of a pandemic. Do you think that if they weren't in the front line of the pandemic, something would have changed? The answer is no, but of course yes, forever.

\section{References}

Balint, M. (1961). Az orvos, a betege es a betegseg. [The Doctor, His Patient and the Illness]. Budapest: Akademiai Kiado

Bruckner, E. (2019). Az elso magyar orvosnok nyomaban. [In the Footsteps of the First Hungarian Female Doctors]. Polgari Szemle, 15, 1-3, 381-398.

Csirak, Cs. (1997). Szatmarnemeti Zsido Korhaz. [Jewish Hospital in Satu- Mare] in Csirak, Cs (1997) Egeszsegugy-torteneti dolgozatok. [ Medical- Historical Papers]. SatuMare, pp. 31, 33,36, 37.

Dancy, J. (2006). Etica indatoririlor prima facie. [The Ethic of duties prima facie]. in Singer,P. (ed). Tratat de etica. [A Companion to Ethics]. Iasi: Polirom, pp 248-258.

Loue, S. (2011). Mentoring Health Science Professionals. New York: Springer, pp. 156.

Marcu, G. \& Ilinca, R. (2009). Dictionarul personalitatilor feminine din Romania. [Dictionary of feminine personalities of Romania]. Bucuresti: Meronia, pp.89-90.

Outram, D. (2008). Panorama iluminismului. [Panorama of the Enlightenment]. Bucuresti: ALL, pp. 273- 275.

Peter H., M. (2005). Nehez kezdet. A nok 100 evvel ezelotti kuzdelme a gyogyszereszi hivatasert. [Hard beginnings. The fight of women for pharmaceutical profession 100 years ago]. Gyogyszeresztortenet. [History of Pharmacy]. 3:4, pp. 12-15.

Schott, H. (ed). (1993). A medicina kronikaja. [The Chronicle of Medicine]. Officina Nova, pp. 286-287.

Szumowszki, U (1939). Az orvostudomany tortenete. [The History of Medicine]. Budapest, pp.89, 422.

Thomann Tewarson, H. (2018). Die ersten Zurcher Arztinnen. [The First Female Doctors in Zurich]. Schwabe Verlag, pp.59.

World Health Organization- WHO. (2020). WHO Director-General's opening remarks at the media briefing on COVID-19 - 11 March 2020. https://www.who.int/directorgeneral/speeches/detail/who-director-general-s-opening-remarks-at-the-media-briefing-on-

COVID-19-11-march-2020 